\title{
INNOVATIONS \\ A model for an academic library and library school mentor/protégé program
}

\author{
By Mary Lynn Rice-Lively \\ Library and Information Science Collection Librarian \\ University of Texas at Austin
}

Any student pursuing an advanced degree often questions the relevance of the curriculum. Students seeking credentials in library and information science are no exception. The correspondence between the academic ideal and the realities of the profession is called into question. Students' queries may include, "How will I know what kind of library or information career I should choose? Who tells me or shows me what really takes place in the day of an information professional? Is involvement in a professional organization truly beneficial, personally and professionally? What is the best way to begin weaving the threads of the professional network all the literature touts as crucial to a successful career?" Graduates of library school programs frequently cite a need to interface the practice of librarianship with the theory. This is particularly true of students who enter the program of study without previous library work experience.

In early 1986 the University of Texas at Austin General Libraries, in cooperation with the Graduate School of Library and Information Science (GSLIS), undertook to provide some practical answers to the professional questions of GSLIS students. Amy Mollberg, then Library and Information Science Collection Librarian, with the guidance of the General Libraries' Associate Director, Linda Cain, implemented a pilot mentoring program. Now in its fifth year, the program allows selected GSLIS students the opportunity to integrate theory into a practical setting through a oneon-one relationship with a librarian.

\section{How the program works}

The mentoring program operates on a semester basis during both fall and spring. A letter of invita- tion goes out to GSLIS students requesting qualified applicants each semester. The qualifications for participation are fairly basic: a GSLIS student/ protégé must have completed at least two of three core library school courses (Introduction to $\mathrm{Li}$ brany and Information Studies, Introduction to Information Resources and Services, or Organization of Materials I) and be recommended by his or her academic adviser. Applicants are screened and matched to a mentor by a committee composed of the Library and Information Science Collection (LISC) Librarian, the General Libraries Assistant Director for Public Services, and the GSLIS Associate Dean.

The LISC librarian issues an annual call for mentors (some of whom have participated in the program for four of the nine semesters it has existed) and maintains a pool of names. A mentor must have been on the staff as a professional librarian in the General Libraries for at least one year. The mentors and protégés are required to commit a minimum of six hours per semester to mentor/ protégé activities.

Volunteer mentors have come from all levels of the General Libraries professional staff, and have included the director of General Libraries, the classics bibliographer, the bibliographic systems officer, an archivist, and members of both the public and the technical services staff. Science librarians have been regularlyinvolved, in response to the strong interest expressed in careers in special or science libraries. Recent trends indicate an increasing number of students are expressing an interest in careers in archives or preservation work. Key considerations during the selection process include the professional career interests of the student and the experience of the mentor. 
The initial meeting of mentors and protégés occurs at a luncheon orientation session hosted by the mentors. A popular activity during this luncheon is sharing information about previous professional experience and training. The basic guidelines for the program as well as possible activities are discussed at the luncheon. Activities have included tours of library operations, discussions of professional and career issues, meetings of library professional staff committees and departments, and shared meals and celebrations.

At the end of each semester, a formal evaluation of the experience is requested. Many of the suggestions provided through this evaluation have been incorporated into the program. For example, although originally only the mentors were asked to evaluate the program, evaluations are now requested from both mentors and students. The

\section{BI in a multicultural environment}

"Cultural Diversity and Higher Eduction: BI in a Multicultural Environment."

The Bibliographic Instruction Section of ACRL will offer a one-day preconference on bibliographic instruction in a multicultural environment on Friday, June 28, 1991, in Atlanta, Georgia.

During the day, four speakers will address major issues concerning cultural diversity and the academic library. The speakers are James Neal (dean, Indiana University Libraries), Janice Koyama (acting assistant provost for letters and sciences, University of California, Berkeley), Sherron Kenton (senior lecturer in communication, Emory Business School), and Mary Huston (assistant professor, Texas Woman's University, School of Library and Information Studies).

Participants can share practical ideas and information by attending three breakout sessions. Topics of breakout sessions include working with international, Chicano, high-risk, and minority students; sensitivity at the reference desk; locating multicultural material; evaluating international and multicultural information sources; and recruiting and retaining diverse staff.

Cost of the preconference is $\$ 145.00$ for ACRL members $(\$ 180.00$ for non-ACRL members) which includes lunch and refreshments. For registration and information contact: Mattye Nelson, professional development officer, (800) 545-2433 x2519, (312) 280-2519; or Reggie Prim, professional development secretary, $x 2526$, (312) 280-2526. starting date of the program has been moved closer to the beginning of the semester as the result of a suggestion that more time is needed to cover the activities and to respond to the interests expressed by the students. The program continues to evolve to meet the needs of both students and library professionals.

\section{Philosophy of the program}

By the end of the spring 1990 semester, 61 students had completed the GSLIS/General Libraries Mentor Program. Although library literature reveals a need for further clarification of the terms mentor and role model, participants in the mentoring program at the University of Texas at Austin have been successful in forging their own models. Whether a mentor is defined as "a wise and trusted counselor and teacher"1 or "an experienced person who provides guidance and support in a variety of ways to the developing novice - by being a role model, guide, tutor, coach or confidant," Michael Fagan's review of the literature concludes that "Mentoring is like . . . any other emotional, social experience; it is hard to define but easy to recognize. ${ }^{23}$ The comments offered on evaluation forms reflect a significant level of satisfaction on the part of both mentors and protégés at having participated in the program. For the relationship to work optimally, the mentor and the protégé must be equally committed to it.

The University of Texas at Austin offers an ideal setting for the mentor program. The university has an enrollment of more than 50,000 students, a library collection of over 6 million volumes, and a professional staff of over 100. The 42-year-old Graduate School of Library and Information Science has an enrollment of over 250 students. The General Libraries administration views the mentor program as an important opportunity to contribute to the GSLIS program. Accordingly, administrators promote the program by encouraging professional staff to participate as part of their work. As a result, librarians are provided with a proactive means to serve as role models for future professionals.

${ }^{1}$ Random House Dictionary of the English Language, 2nd ed. (New York: Random House, 1987), 1201 .

${ }^{2}$ B. Bolton, "A Conceptual Analysis of the Mentor Relationship in the Career Development of Women," Adult Education 30 (Summer $1980): 195-207$.

${ }^{3}$ Michael Fagan, "The Term Mentor:A Review of the Literature and a Pragmatic Suggestion," International Journal of Mentoring 2 (Winter 1988):5-8. 